\title{
Case Report of the Patient with Acute Myocardial Infarction: "From Flatline to Stent Implantation"
}

\author{
Dejan Petrović ${ }^{1,2}$, Marina Deljanin Ilićc1,2, Bojan Ilić ${ }^{1}$, Sanja Stojanović1, \\ Milovan Stojanović ${ }^{1}$, Dejan Simonović ${ }^{1}$ \\ ${ }^{1}$ University of Niš, Faculty of Medicine, Niš, Serbia \\ 2Institute for Treatment and Rehabilitation, "Niška Banja", Niška Banja, Serbia
}

\begin{abstract}
SUMMARY
Asystole is a rare primary manifestation in the development of sudden cardiac death (SCD), and survival during cardiac arrest as the consequence of asystole is extremely low. The aim of our paper is to illustrate successful cardiopulmonary resuscitation (CPR) in patients with acute myocardial infarction (AMI) and rare and severe form of cardiac arrest - asystole. A very short time between cardiac arrest in acute myocardial infarction, which was manifested by asystole, and the adequate CPR measures that have been taken are of great importance for the survival of our patient.

After successful reanimation, the diagnosis of anterior wall AMI with ST segment elevation was established. The right therapeutic strategy is certainly the early primary percutaneous coronary intervention (PPCI). In less than two hours, after recording the "flatline" and successful reanimation, the patient was in the catheterization laboratory, where a successful PPCI of LAD was performed, after emergency coronary angiography. In the further treatment course of the patient, the majority of risk factors were corrected, except for smoking, which may be the reason for newly discovered lung tumor disease. Early recognition and properly applied treatment of CPR can produce higher rates of survival.
\end{abstract}

Key words: sudden cardiac death, asystole, cardiopulmonary resuscitation 


\section{INTRODUCTION}

Sudden cardiac death (SCD) represents natural, unexpected death that occurs within one hour of the onset of acute symptoms (1). Sudden cardiac death may occur in apparently healthy individuals who have not been affected by any type of cardiovascular disease or in patients with stable cardiovascular disease. The incidence of SCD in America amounts to 180 and 450 thousand (2). It is estimated that about $15 \%$ to $20 \%$ of the total mortality is the result of SCD (3). It is significantly more common in male patients (4), and frequency increases with aging in both genders (5).

Sudden cardiac death is most often caused by coronary heart disease (CHD). More than $80 \%$ of sudden deaths are the result of different categories of coronary diseases and over $50 \%$ of coronary patients die from sudden cardiac death (6). This is also confirmed by an increase in SCD incidence with age, as the number of CHD increases with age. Sudden cardiac death may represent the first manifestation of coronary disease but is more common in patients with already established ischemic heart disease and apparently stable disease state. The mechanism of SCD development in coronary patients is complex and is related to vascular pathophysiology, myocardial pathophysiology, as well as numerous systemic factors (7). Multivessel coronary artery disease is found in more than $75 \%$ of coronary patients with SCD (7).

Rare etiological factors of SCD include cardiac failure, cardiac hypertrophy, cardiac rhythm and conduction disorders, valvular cardiac diseases, heart tumors, heart sarcoidosis, heart amyloidosis, etc. (8-10). Non-cardiac causes of SCD may include: infections, drug poisoning, trauma, and malignancies.

Cardiac arrest is a reversible phase in the development of sudden cardiac death, in case when cardiopulmonary resuscitation (CPR) measures are applied very quickly and adequately (11). Cardiac arrest is the most emergent and most dramatic condition that is manifested by rapid loss of consciousness, as the brain function stops for fifteen seconds after cessation of circulation, absence of pulse on large arteries, cessation of breathing, cyanosis, and appearance of grayish skin color and dilation of pupils.

Electrocardiogram is the only method that can distinguish four forms of cardiac arrest: ventricular fibrillation, ventricular tachycardia without pulse, electromechanical dissociation, and asystole. Asystole is a rare primary manifestation in the development of SCD (in $10-30 \%$ of patients) and survival in cardiac arrest as the consequence of asystolia (asystole) is extremely low (lower than $1 \%$ ).

\section{A I M}

The aim of our paper is to illustrate successful cardiopulmonary resuscitation in patients with acute myocardial infarction (AMI) and rare and severe form of cardiac arrest - asystole (flatline on the tape).

\section{CASE REPORT}

A 56-year-old male (P.S.) felt chest pain in the morning, and accompanied by his wife, was brought to emergency department of the Institute of Niška Banja. Immediately after the admission, he complained of severe dizziness and in a few seconds he lost his consciousness. Blood pressure values were unmeasurable, pulse was impalpable on large arteries, periphery was cold and cyanosis was prominent. A straight line was registered on the defibrillator monitor (Figure 1). The patient was immediately intubated, CPR measures (massage, ventilation) started, and a venous access was opened. Shortly after the application of adrenaline, ventricular fibrillation was recorded on the defibrillator monitor (Figure 2). Defibrillation was performed (360J) and ventricular rhythm was established (Figure 3).

\subsubsection{3.}

\section{$11: 02 \mathrm{~h}$}

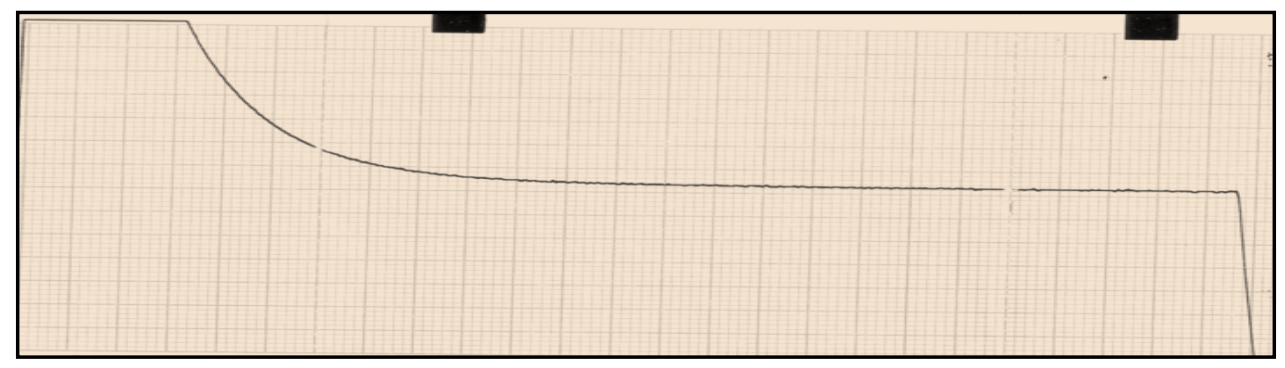

Figure 1. Part of the recording from the defibrillation tape on which a straight line was registered, i.e. asystole 
12.11.2013.

11:05h

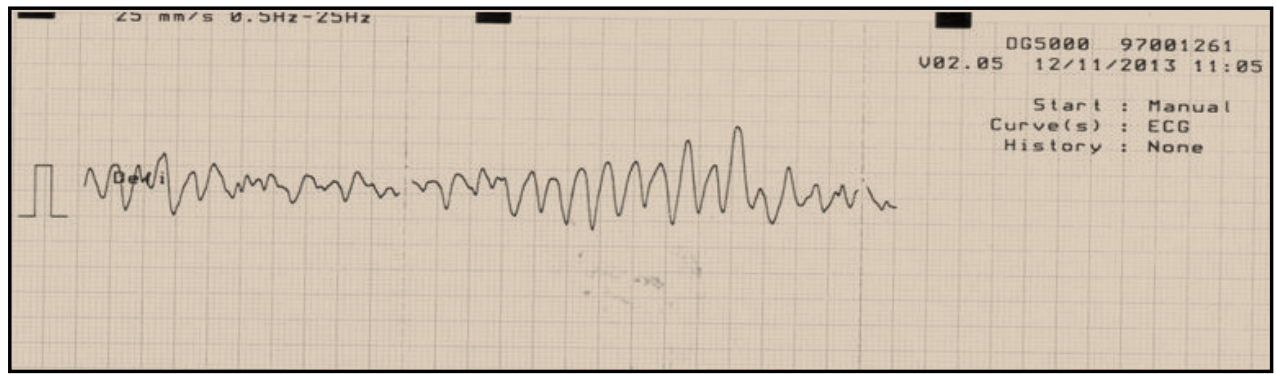

Figure 2. Part of the recording from defibrillation tape on which ventricular fibrillation was registered

12.11.2013.

$11: 10 \mathrm{~h}$

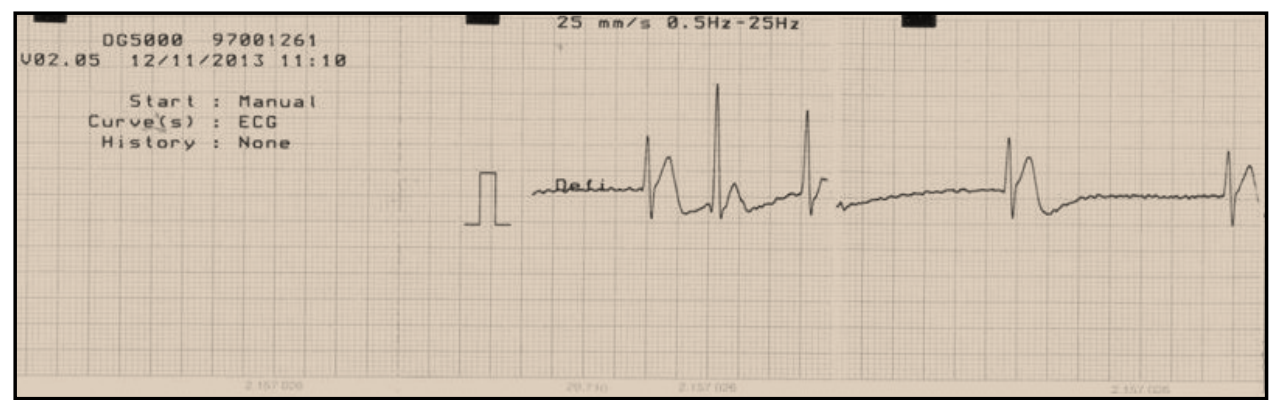

Figure 3. Part of the recording from defibrillation tape on which satisfactory ventricular activity was recorded

In a coronary care unit on electo-cardiogram, ST eelevation was recorded (Figure 4) and therapy according to STEMI protocol was administered (clexan, aspirin, clopidogrel, pantopazol, phentanyl, atorvastatin).

12.11.2013.
The patient was immediately referred to the Clinic for Cardiovascular Diseases, Clinical Center Niš for urgent coronary angiography. The coronary angiography finding showed the presence of a twovessel coronary disease (LAD subocclusion, RCA stenosis 80\%), (Figure 5).

\section{$11: 38 \mathrm{~h}$}

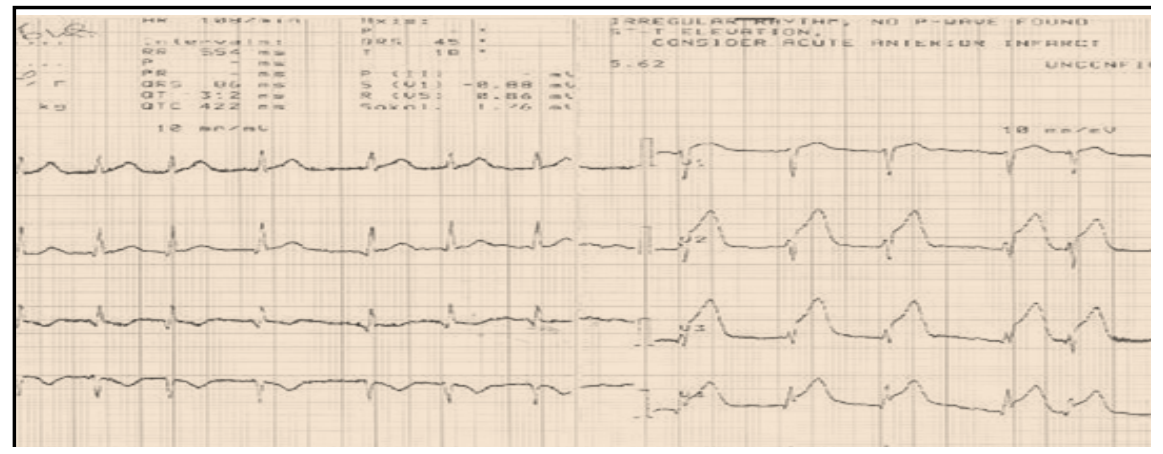

Figure 4. Electrocardiogram of the patient P.S. (registered in coronary care unit) shows the signs of acute myocardial infarction of the anterior wall 


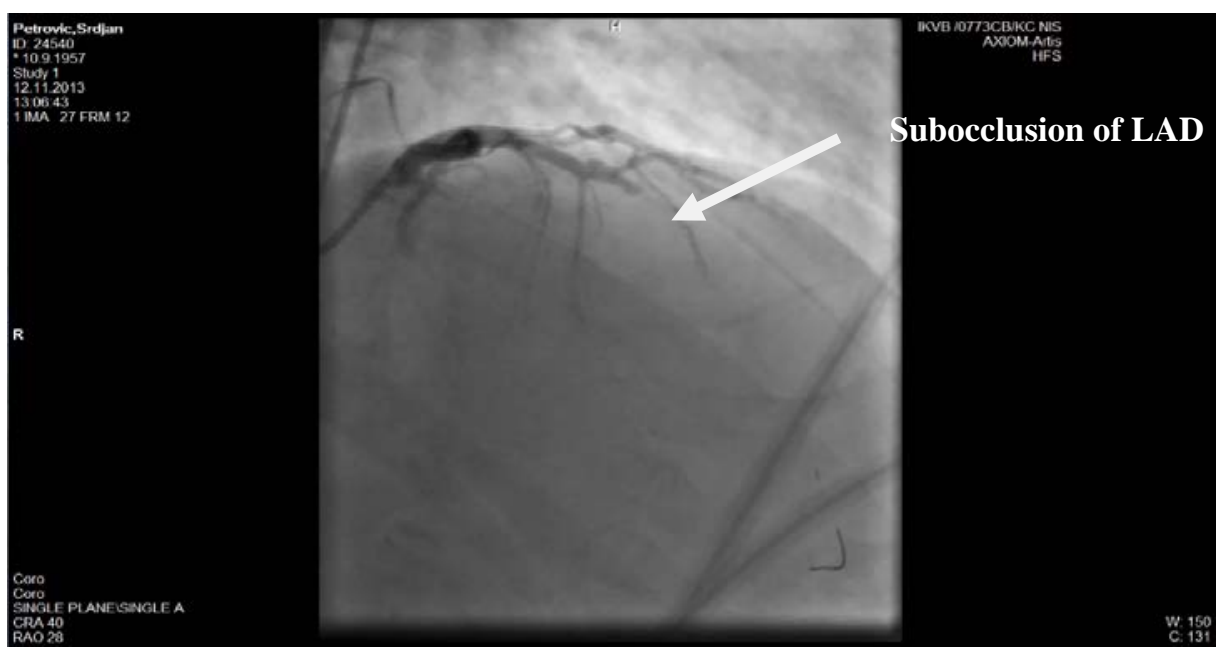

Figure 5. Coronary angiography of the patient PS shows a two-vessel coronary disease

Primary percutaneous intervention with implantation of stent in LAD was performed.

After the primary percutaneous intervention with implantation of a single stent in LAD, the patient was returned to the Institute of Niška Banja, where intensive monitoring, treatment and early hospital rehabilitation continued.

Figure 7 shows an electrocardiogram of the patient three days after the onset of acute myocardial infarction. The following risk factors for CHD are were present: long-lasting hypertension, elevated cholesterol and triglycerides levels, long lasting smoking of 50 cigarettes a day and newly discovered diabetes mellitus.
During hospital treatment, elevated values of cardiospecific enzymes and lipids were found. The glycemic value was also significantly increased (10.3 $\mathrm{mmol} / \mathrm{l})$. The echocardiographically estimated ejection fraction was $45 \%$ with the akinetic apex of the left ventricle, while the upper third of the free left ventricular wall and the inferior wall were hypokinetic. A 24-hour holter electrocardiogram showed a low incidence (total of 19) of individual, uniform ventriculary premature beats and low heart rate variability (SDNN 56.9 msec).

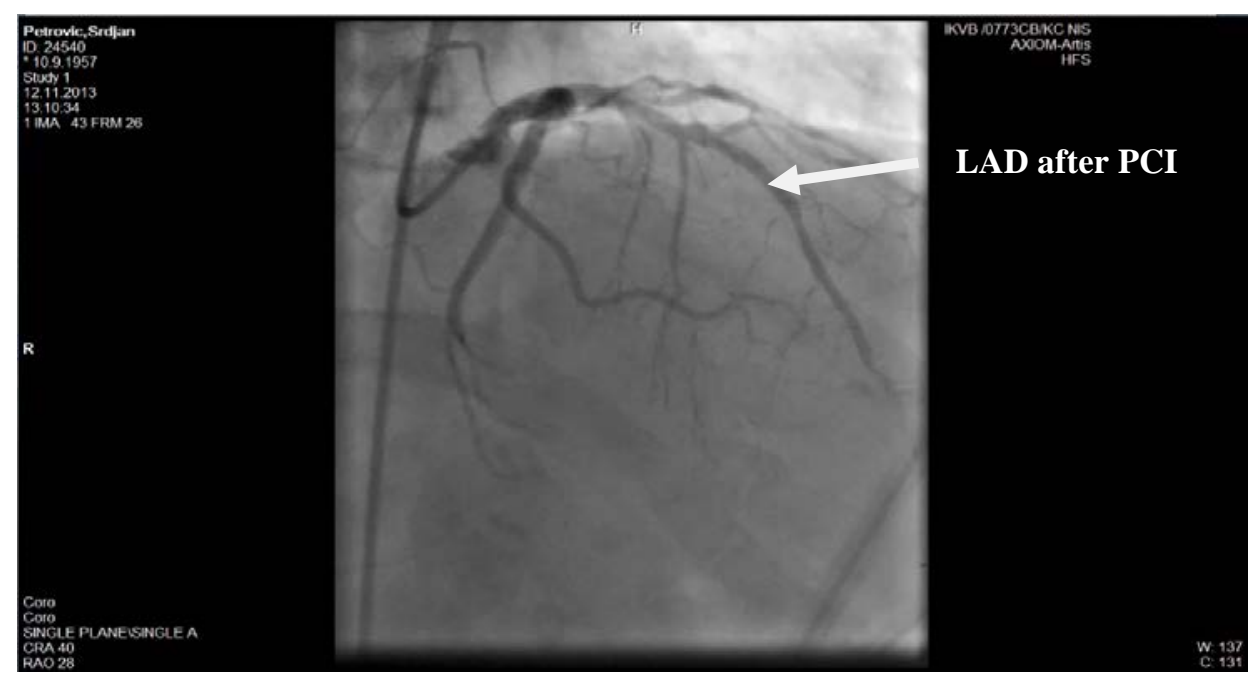

Figure 6. Coronary angiography of the patient P.S. after PPCI on LAD 


\section{(stentimplantation)}

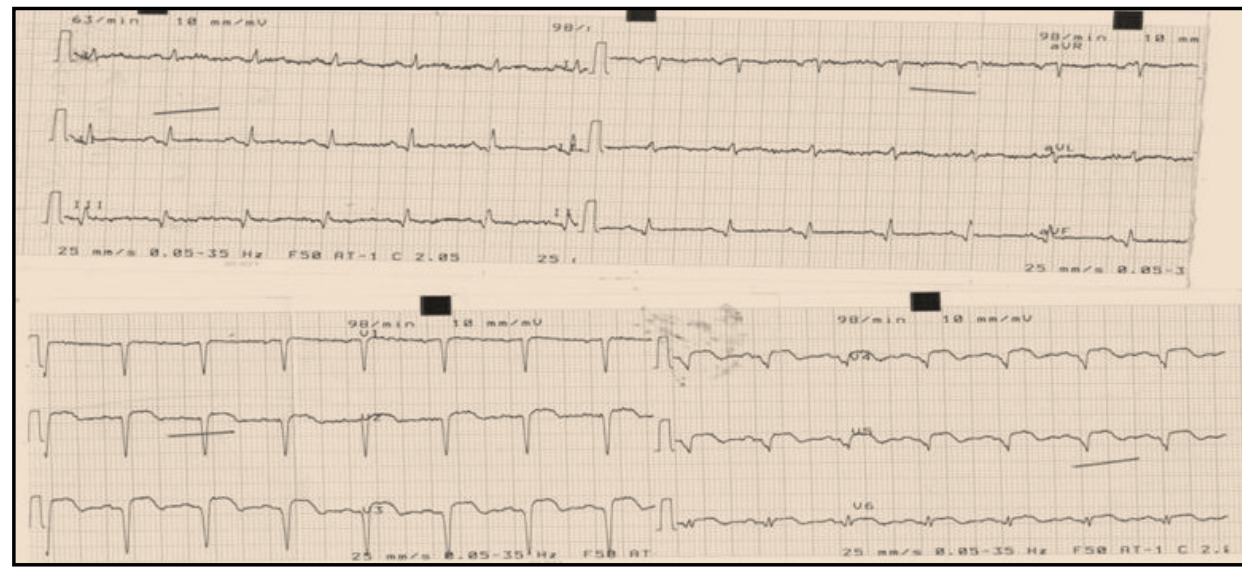

Figure 7. Electrocardiogram of the patient P.S. on the third day after acute myocardial infarction (15.11.2013.)

The patient had no recurrent anginal pain nor the symptoms and signs of heart failure. On hospital discharge, the life style changes were advised (cessation of smoking, diet with less salt and fat, more fruits and vegetables, everyday physical activity not causing subjective problems, posthospital rehabilitation and drug therapy for secondary prevention was prescribed.

Over the next three years after infarction and pPCI LAD, there were no significant cardiovascular events. At the end of 2016, the patient started to feel uneasiness in the chest that radiated to his shoulders, regardless of physical effort. Due to these problems, he was treated at the Clinic for Cardiology, the Institute of Niška Banja in November 2016. At that time, he underwent ergo test and ECG holter but no ischemic changes were registered. During this hospitalization, accelerated sedimentation of erythrocytes (85/h) was found.

At the beginning of 2017, after radiological examination, a left pulmonary lung tumor with a large pleural effusion was identified, and bronchopulmonary examination and further pulmology treatment were carried out.

\section{DISCUSSION}

Electrical mechanisms of cardiac arrest are in most cases tachyarrhythmic - ventricular fibrillation or prolonged ventricular tachycardia that significantly disrupts circulation and progresses to ventricular fibrillation. Bradyarrythmic-asystolic mechanisms (asystole and electromechanical dissociation) are significantly rarer. Patients in whom asystole was registered at the time of the first medical contact have significantly higher mortality rate.

The most common marker for the tendency to heart failure and SCD is low EF (but it is impossible to predict the occurrence of SCD in coronary patients in whom cardiac arrest is the first clinical manifestation of the disease). Other predictors should be noted - T wave alternans, prolonged QT interval, QT dispersion, accelerated heart rate at rest, weak heart rate increase at effort, as well as slow deceleration of heart rate in the first minute of recovery from the load, registering of a higher number of VES during holter monitoring (more than 10/h and short-term episodes of ventricular tachycardia). However, acute ischemia and necrosis in acute myocardial infarction and consequent electrical abnormalities that contribute to the emergence of SCD should not be ignored.

The basic principle in the treatment of cardiac arrest is to establish circulation as early as possible and provide continuous support to the blood flow system until its normal spontaneous function is enabled. Cardiopulmonary resuscitation should begin with the punching in the chest (at the junction of the middle and lower third of the chest bone). If this maneuver does not help it should not be repeated, and cardiopulmonary resuscitation should be performed instead. The airway should be released, the artificial ventilation and artificial circulation are carried out from the beginning to the end of resuscitation. The survival rate goes beyond $30 \%$ if cardiopulmonary 
resuscitation begins in the first minute of the loss of consciousness (12).

Defibrillation is the main method in resuscitation if ventricular fibrillation is concerned. It should be carried out urgently and measures to stabilize heart rhythm disturbance should be continued to maintain circulation so as to reverse organ damage, that is, the damage of the central nervous system in particular, because it represents a strong predictor of intrahospital mortality. Also, the strategy of early application of hypothermia in order to reduce metabolic needs and brain edema is beneficial in reducing mortality. Resuscitation in asystole is significantly less successful than in the ventricular fibrillation. Adrenaline $1 \mathrm{mg}$ (1: 10.000) should be administered and repeated, if necessary, for five minutes.

After successful resuscitation, further therapy is carried out in hospital conditions and depends on the primary cause of cardiac arrest. In patients with acute myocardial infarction, the primary percutaneous intervention is performed to open the infarct-related artery $(13,14)$. In order to reduce cerebral symptomatology due to edema of the lungs, an antiedemetic therapy involving dexamethasone and furosemide is used.

In prevention of SCD, antiarrhythmic drugs have not shown significant efficacy, and class I antiarrhythmics should not be used $(15,16)$.

The administration of amiodarone neither led to a significant decrease in mortality $(17,18)$. Only the combination of amiodarone and beta-blockers has shown some efficacy in reduction of SCD (19).

Today, the implantable cardioverter defibrillator (ICD) is the only form of prevention and treatment that has proven efficacy in the prevention of SCD and total mortality (20). In primary prevention, ICD is effective in patients with EF $\leq 40 \%$ who have short-term VT and prolonged monomorphic VT-induced in electrophysiological tests, and in patients with $\mathrm{EF} \leq 30 \%$ as a result of a heart attack.

\section{CONCLUSION}

Our case report deserves attention for many reasons.

Firstly, cardiac arrest in acute myocardial infarction was primarily manifested as an asystole, which represents a rarer manifestation than ventricular fibrillation. Most often, asystole, that is, the straight line on the electrocardiogram is observed as a failure in resuscitation of ventricular fibrillation.

Secondly, rapid resuscitation was effective in patients with asystole, and it is well known that survival in cardiac arrest due to asystole is very rare.

Thirdly, early primary percutaneous coronary intervention is possible if the patient is referred on time from the institution without possibillity for coronary angiography to the institution with high quality equipment and highly trained medical staff.

Fourthly, adequate risk factor control and appropriate drug therapy for secondary prevention represent a guarantee for long-lasting survival without new cardiovascular events.

Fifthly, the prognosis of the patient is significantly deteriorated by the lung tumor, probably as a result of long-term smoking of a large number of cigarettes. 


\section{References}

1. Zipes DP, Camm AJ, Borggrefe $M$, et al ACC/AHA/ESC 2006 guidelines for management of patients with ventricular arrhythmias and the prevention of sudden cardiac death - executive summary: Eur Heart J 2006;27:2099-140. https://doi.org/10.1016/j.jacc.2006.07.008

2. Loyd JD, Adams RJ, Brown TM, et al. Heart disease and stroke statistics - 2010 update: a report from the American Heart Association. Circulation 2010; 121:e46-215.

https://doi.org/10.1161/CIRCULATIONAHA.109.19 $\underline{2667}$

3. Gillum RF. Gographic variation in sudden coronary death. Am Heart J 1990; 119:380-9.

https://doi.org/10.1016/S0002-8703(05)80031-6

4. Simmons A, Pimental R, Lakkireddy D. Sudden cardiac death in women. Rev Cardiovasc Med 2012; 13:e37-42.

5. Zheng ZJ, Croft JB, Giles WH, Mensah GA. Sudden Cardiac Death in the United States, 1989 to 1998. Circulation 2001; 104:2158-63.

https://doi.org/10.1161/hc4301.098254

6. Myberg RJ, Castellanos A. Cardiac Arres and Sudden Cardiac Death. In: Zipes DP, Libby $P$, Bonow RO, Braunwald E, editors. Braunw-ald s Heart Disease. A Textbook of Cardiovascular Medicine. Philadelphia: Elsevir Saunders, 2005; 865908.

7. Myberg R, Juntilla MJ. Sudden Cardiac Death caused by Coronary Heart disease. Circulation 2012; 125:1043-52.

https://doi.org/10.1161/CIRCULATIONAHA.111.02 $\underline{3846}$
8. Vimani R, Burke AP, Farb A. Sudden cardiac death. Cardiovascular pathology 2001; 10:211-8. https://doi.org/10.1016/S1054-8807(01)00091-6

9. Lopshire JC, Zipes DP. Sudden cardiac death. Circulation 2006; 114:1134-6. https://doi.org/10.1161/CIRCULATIONAHA.106.64 $\underline{7933}$

10. Tedesco C, Reigle J, James B. Sudden cardiac death in heart failure. Journal of Cardiovascular Nursing 2000; 14:38-56.

https://doi.org/10.1097/00005082-200007000-00004

11. Koenraad G. Monsieurs, Jerry P Nolan, Leo 1. Bossaert, et al: European Resuscitation Council Guidelines for Resuscitation 2015;95:81-99.

12. Trpković S, Pavlović A, Videnović N et al. Značaj uspostavljanja disajnog puta i rane defibrilacije na preživljavanje pacijenata koji su doživeli vanbolnički akutni zastoj srca. Praxis medica 2010; 38:33-8.

13. Keeley EC, Boura JA, Grines CL. Primary angioplasty versus intravenous thrombolytic therapy for acute myocardial infarction: a quantitative review of 23 randomised trials. Lancet. 2003 Jan 4; 361(9351):13-20. https://doi.org/10.1016/S0140-6736(03)12113-7

14. Andersen HR, Nielsen TT, Rasmussen K. A comparison of coronary angioplasty with fibrinolytic therapy in acute myocardial infarction $\mathrm{N}$ Engl J Med. 2003 Aug 21; 349(8):733-42. https://doi.org/10.1056/NEIMoa025142

15. Cardiac Arrhythmia Suppression Trial (CAST) Investigators. Preliminary report: effect of encainide and flecainide on mortality in a randomized trial of arrhythmia suppression after myocardial infarction. N Engl J Med. 1989; 321:406-12. https://doi.org/10.1056/NEJM198908103210629 
16. Priori S, Blomström-Lundqvist $C$, Mazzanti A, et al. 2015 ESC Guidelines for the management of patients with ventricular arrhythmias and the prevention of sudden cardiac death: Eur Heart J 2015;36:27932867.

https://doi.org/10.1093/eurheartj/ehv316

17. Julian DG, Camm AJ, Frangin G, et al. Randomised trial of effect of amiodarone on mortality in patients with left ventricular disfunction after recent myocardial infarction: EMIAT. European Myocardial Infarct Amiodarone Trial Investigators. Lancet 1997; 349:667-76.

https://doi.org/10.1016/S0140-6736(96)09145-3

18. Cairns JA, Connolly SJ, Roberts R, Gent M. Randomised trial on outcome after myocardial infarction in patients with frequent or repetitive ventricular premature depolarisations: CAMIAT.
Canadian Amiodarone Myocardial Infarction Arrhythmia Trial Inestigators. Lancet 1997; 349:67586.https://doi.org/10.1016/S0140-6736(96)08171-8

19. Boutitie F, Boissel JP, Connolly JP, et al. Amiodarone interaction with beta-blockers: analysis of the merged EMIAT (European Myocardial Infarct Amiodarone Trial) and CAMIAT(Canadian Amiodarone Myocardial Infarction Arrhythmia Trial) databases. Circulation 1999; 99:2268-76.

https://doi.org/10.1161/01.CIR.99.17.2268

20. Moss AJ, Zareba W, Hall WJ, et al. Prophylactic implantation of a defibrilator in patients with myocardial infarction and reduced ejection fraction. N Engl J Med 2002; 346:877-85.

https://doi.org/10.1056/NEJMoa013474 


\title{
Prikaz bolesnika sa akutnim infarktom miokarda „od ravne linije do ugradnje stenta“
}

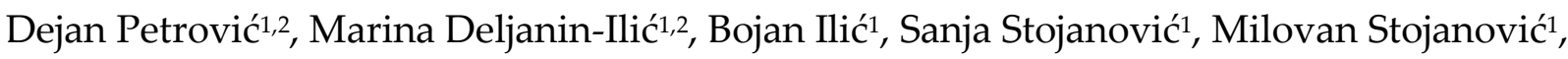 \\ Dejan Simonović ${ }^{1}$ \\ ${ }^{1}$ Univerzitet $u$ Nišu, Medicinski fakultet, Niš, Srbija \\ 2Institut za lečenje i rehabilitaciju "Niška Banja", Niška Banja, Srbija
}

\section{SAŽETAK}

Asistolija je ređa primarna manifestacija kod nastanaka iznenadne srčane smrti (ISS), a preživljavanje kod srčanog zastoja usled asistolije je veoma nisko.

Cilj našeg prikaza bio je uspešna kardiopulmonalna reanimacija (KPR) kod bolesnika sa akutnim infarktom miokarda (AIM) i ređim, a težim oblikom srčanog zastoja - asistolijom. Veoma kratko vreme između srčanog zastoja u akutnom infarktu miokarda, koji se manifestovao asitolijom, i preduzetih adekvatnih mera KPR-a, uslov je preživljavanja našeg bolesnika.

Nakon uspešne reanimacije, postavljena je dijagnoza AIM anterione lokalizacije sa elevacijom ST segmenta. Prava terapijska strategija je sigurno rana primarna perkutana koronarna intervencija (PPCI). Za manje od $2 \mathrm{~h}$ nakon registrovanja "ravne linije“ i uspešne reanimacije, bolesnik je bio u Sali za kateterizaciju, gde mu je nakon urgentne koronarografije, urađena i uspešna pPCI na LAD. U daljem lečenju bolesnika korigovana je većina faktora rizika, osim pušenja, što je možda i razlog novootkrivene bolesti tumora pluća. Rano prepoznavanje i pravilno primenjene mere KPR-a u velikoj meri doprinose smanjenju smrtnosti i uspešnom oporavku ovakvih bolesnika.

Ključnereči: iznenadna srčana smrt, asistolija, kardiopulmonalna reanimacija 